\title{
Green Concrete: Efficient \& Eco-Friendly Construction Materials
}

\author{
Ms.Duhita H. Doye \\ ${ }^{I}$ Assistant Professor, DMIETR, Wardha
}

\begin{abstract}
New technologies have evolved very fast to cater different difficulties in the construction industry. Production of concrete which will leave a substantial mark on the environment.The concrete is made with concrete wastes which are eco-friendly so called as Green concrete. The paper covers the aspect on how to choose a material forgreen concrete. It presents the feasibility of the usage of by product materials like fly ash, query dust, marblepowder/ granules, plastic waste and recycled concrete and masonry as aggregates in concrete. By the use of green concrete it is possible to reduce the CO2 emission in atmosphere. To avoid the pollution and reuse the material, the present study is carried out. Thus, green concrete is an excellent substituent of cement as it is cheaper, because it uses waste products, saving energy consumption in the production, greater strength and durability than the normalconcrete.
\end{abstract}

Key Words: Eco-Friendly Concrete, Eco-Friendly Construction Material, Efficient Concrete, Green Concrete

\section{Introduction}

concrete is themost used man-made product in the world.Concrete is a major contributor togreenhouse gas emissions and creates problem for the disposalof waste concrete from demolished sites which in turn effectsthe environment.[1] Therefore recycling of concrete waste is theneed of hour. Concrete is also interesting in relation to otherenvironmental problems than those related to $\mathrm{CO} 2$ emission.Due to all these above mentioned reasons civil engineers havecome up with a new concept of concrete, named "GREENCONCRETE".

The availability of natural resources to future generations has also been realized. The size of construction industry all over the world is growing at faster rate".[2] Concrete is a widely used construction material consisting of cementing material, fine aggregate, coarse aggregate and required quantity of water, where in the fine aggregate is usually natural sand. The use of sand in construction results in excessive sand mining which is objectionable. Due to rapid growth in construction activity, the available sources of natural sand are getting exhausted.

Waste can be used to produce new products or can be used as admixtures so that natural resources are limited and used more efficiently and the environment is protected from waste deposits. [3] Inorganic residual products like stone dust,crushed concrete, marble waste are used as green aggregates in concrete. Further, by replacing cement with fly ash, micro silica in larger amounts, to develop new green cements and binding materials, increases the use of alternative raw materials and alternative fuels by developing or improving cement with low energy consumption. Considerable research has been carried out on the use of various industrial byproducts and micro-fillers in concrete. The main concern of using pozzolanic wastes was not only the cost effectiveness but also to improve the properties of concrete, especially durability.[4]

This paper summarizes the various efforts underway to improve the environmental friendliness of concrete tomake it suitable as a "Green Building" material. Foremost and most successful in this regard is the use suitable substitutes for Portland cement, especially those that are by products of industrial processes, like fly ash, ground granulated blast furnace slag, and silica fume. Also efforts to use suitable recycled materials as substitutes for concrete aggregate are gaining in importance, such as recycled concrete aggregate etc.

\section{Material/Product Selection Criteria}

Overall material/product selection criteria:

- Resource Efficiency: Resource efficiency basically includes properties like recycled content, natural orrenewable, resource efficient manufacturing process, locally available, salvaged/refurbished or remanufactured,reusable or recyclable and durability.

- Indoor Air Quality: Indoor air quality (IAQ) is enhanced by utilizing materials that meet the followingproperties: low or non-toxic, minimal chemical emission, moisture resistant and healthfully maintained.

- Energy Efficiency: This mainly refers to the energy used for making the concrete. Those materials are preferredthat require the minimal amount of energy at the time of construction of the concrete. 
- Water Conservation: Materials that help us and conserve water in landscaped areas are preferred to be used asconstruction save water at the time of construction or even help reduce water consumption in building materials.

- Affordability: Affordability can be considered when building product life-cycle costs are comparable toconventional materials or as a whole, are within a project-defined percentage of the overall budget.

\section{Replacement of Materials For Green Concrete \\ Cement: Ex. Eco-Cement, Sludge Ash, Municipals Solid Waste Fly Ash \\ Fly Ash as Cementations Material}

When pulverized coal is burnt to generate heat, the residue contains $80 \%$ fly ash and $20 \%$ bottom ash. Fly ash produced in Indian power stations are light to mid-grey in color and have the appearance of cement powder. Use of Fly ash concrete in place of PCC will not only enable substantial savings in the consumption of cement and energy but also provide economy. The use of fly ash has a number of advantages. It is theoretically possible to replace $100 \%$ of Portland cement by fly ash, but replacement levels above $80 \%$ generally require a chemical activator. Studies have found that the optimum replacement level is around $30 \%$. Moreover, fly ash can improve certain properties of concrete, such as durability. Because it generates less heat of hydration, it is particularly well suited for mass concrete applications. The use of fly ash in concrete in optimum proportion has many technical benefits and improves concrete performance in both fresh and hardened state. Fly ash use in concrete improves the workability of plastic concrete, and the strength and durability of hardened concrete. Generally, fly ash benefits concrete by reducing the mixing water requirement and improving the paste flowbehaviour.

Course Aggregate: Ex. Fly Ash Aggregate, Recycled Aggregates, Masonarywaste Ready Mix Concrete, Waste Glass, Recycled Aggregates with Crushed Glass, Recycled Aggregates with Silica Fume.

\section{Fly Ash Aggregates}

Several lightweight concrete aggregates can be produced from fly ash. In addition to the use of furnace bottom ashin concrete masonry, pellets of fly ash can be bound by thermal fusion or chemically, using cement or lime. Such materialshave many desirable properties. In the mid-1990s, Pacific Power conducted a feasibility study [2] of the production of sintered fly ash aggregates(Powerlyte) and examined the use of such aggregates in concrete production. Fly ash was palletized and fired at controlledtemperature to produce synthetic coarse and fine aggregates. These fly ash aggregates have a specific gravity range of $1.20-1.47$, a bulk density range of $650-790 \mathrm{~kg} / \mathrm{m}^{3}$ andvery high absorption from $16-24.8 \%$. These properties showed very positive results for using fly ash as aggregates.

\section{Recycled Concrete and Masonry as Aggregates}

Coarse recycled concrete and masonry (RCM) is graded aggregates produced from sorted and clean wasteconcrete and masonry typically for road soubise applications. The material may contain small quantities of bricks, gravel,crushed rock or other forms of stony material as blended material. Fine recycled aggregates may also be referred to ascrushed concrete fines. The shape, grading and excessive amount of fines may impact the workability, bleeding rate,finish ability and susceptibility to plastic cracking of concrete. Manufactured sand can be used to replace a majorproportion of natural sand with no significant loss of performance in cement based products.

FINE AGGREGATE: Common river sand is expensive due to excessive cost of transportation from natural sources. Also large-scale depletion of these sources creates environmental problems. As environmental transportation and other constraints make the availability and use of river sand less attractive, a substitute or replacement product for concrete industry needs to be found. River sand is most commonly used fine aggregate in the production of concrete poses the problem of acute shortage in many areas. Whose continued use has started posing serious problems with respect to its availability, cost and environmental impact.Use of Quarry rock dust as a fine aggregate in concrete draws serious attention of researchers and investigators. Advantages of quarry dust concrete:

- The durability of quarry dust concrete under sulphate attack is higher compared to conventional concrete.

- The durability of quarry dust concrete under acid action is also better than conventional concrete.

- The effects of quarry dust on the elastic modulus property are good with conventional concrete containing natural sand.

- The fine quarry dust tends to increase the amount of super plasticizers needed for the quarry mixes in order to achieve the rheological properties. 


\section{Suitability of Green Concrete In Structures}

Several factors which enhance the suitability of green concrete in structures include:

- Reduce the dead weight of a structure.

- Good thermal and fire resistance, sound insulation.

- Shorten overall construction period.

- Reduction of the concrete industry's CO2-emission by $30 \%$.

- Increased concrete industry's use of waste products by $20 \%$.

- No environmental pollution and sustainable development.

- Green concrete requires less maintenance and repairs.

- Green concrete sometimes give better workability than conventional concrete.

- Compressive strength behavior of concrete with water cement ratio is more than that of conventional concrete.

- Flexural strength of green concrete is almost equal to that of conventional concrete.

\section{Conclusions}

- There is significant potential in waste materials to produce green concrete.

- The replacement of traditional ingredients of concrete by waste materials and by products gives an opportunity to manufacture economical and environment friendly concrete.

- Partial replacement of ingredients by using waste materials and admixtures shows better compressive and tensile strength, improved sulphate resistance, decreased permeability and improved workability.

- The cost per unit volume of concrete with waste materials like quarry dust is lower than the corresponding control concrete mixes.

- A detail life cycle analysis of green concrete by considering various parameters is very much necessary to understand the resultant concrete properties.

- Use of concrete productlike green concrete in future will not only reduce the emission of $\mathrm{CO} 2$ in environment and environmental impact but it isalso economical to produce.

\section{References}

[1]. Swamy RN, Mehmod HB. Mix proportions and strength characteristics of concrete containing 50\% low calciumfly ash. In: Malhotra VM, editor. Proceedings of the second international congress on fly ash, silica fume, slag andnational pozzolanas in concretes, Madrid, ACJ SP 91, vol. 1; 1986. p. 413-32.

[2]. Orsos, T., 'BST: The Lightweight concrete aggregate', Concrete Institute of Australia seminar on Special UseConcretes, Melbourne, 1992.

[3]. Ahmed E. Ahmed and Ahmed A. E. kourd.1989. Properties of concrete incorporating natural and crushed stonevery fine sand.ACI Material journal.86 (4):417-424.

[4]. Rebeiz, K. S., 1996. Precast use of polymer concrete using unsaturated polyester resin based on recycledPET waste. Construction and Building Materials 10 (3), 215-220. 